\title{
Miranda
}

Revue pluridisciplinaire du monde anglophone /

Multidisciplinary peer-reviewed journal on the English-

speaking world

$21 \mid 2020$

Modernism and the Obscene

\section{The Challenge of Taking Sides: Virtue as Corruption in Joyce's Ulysses}

\section{Philippe Birgy}

\section{OpenEdition}

\section{Journals}

Electronic version

URL: http://journals.openedition.org/miranda/28067

DOI: 10.4000/miranda.28067

ISSN: 2108-6559

Publisher

Université Toulouse - Jean Jaurès

\section{Electronic reference}

Philippe Birgy, "The Challenge of Taking Sides: Virtue as Corruption in Joyce's Ulysses", Miranda [Online], 21 | 2020, Online since 09 October 2020, connection on 16 February 2021. URL: http:// journals.openedition.org/miranda/28067 ; DOI: https://doi.org/10.4000/miranda.28067

This text was automatically generated on 16 February 2021.

\section{(a) $(\triangle \Theta$}

Miranda is licensed under a Creative Commons Attribution-NonCommercial-NoDerivatives 4.0 International License. 


\title{
The Challenge of Taking Sides: Virtue as Corruption in Joyce's Ulysses
}

\author{
Philippe Birgy
}

\section{Introduction}

The presence of obscenity in Joyce's writing and the suspicion of pornographic content have given rise to hesitant sentiments in its readers concerning the reactions these materials were meant to excite and the position they should adopt in relation to them. Many readers have doubted the appropriateness of their own response, wondering whether the problematic contents were designed to attract or repulse. This preoccupation, framed by the moral scandal which the publication of Ulysses had caused, had already been at the center of the 1921 trial. $^{1}$

I wish to examine the exact tenor of such reactions, taking into consideration the critical production devoted to the question of obscenity, censorship and pornography in Joyce's work (Birmingham, Cotter, Mullin, Pease, Potter, Potter and Bradshaw, Vanderham) and paying special attention to "Nausicaa," a chapter that was the bone of contention in the 1921 trial. It is the configuration of its narrative apparatus which, I will argue, has caused the readers to toss restlessly between different critical options, prodded on by misgivings about possible authorial intentions.

I wish to start with a preliminary reading of "Nausicaa" examining the fluctuating and somewhat contradictory instructions which the text seems to be giving its readers. This close reading will allow me not only to outline some conflicting interpretations of the text, but more importantly, to chart the textual turbulence that keeps dislodging the reader from any of these stations, forcing that reader to move between them in accordance with the text's sway. For all the motions the text induces are less invitations than orders. And whether one goes with the narrative flow or is prompted 
to disengage from it to discipline and reason it out, one is obeying contradictory commands.

Accordingly, I will focus first on the formal/discursive features producing the conflict of interpretations: I am thinking of the irreducible ambiguity of the system of enunciation and focalization, which allows two divergent readings, even if both interpretations are associated with a revulsive reaction; I am also thinking of the polyphonic interweaving in Joyce's text of different discourses on women, on their purity and the corruption of that purity, which leads to different types of assessments of what is ultimately being exposed in Joyce's text. Having clarified these points, I will then concentrate on the characterization of the female subject and the degree of autonomy it can possibly negotiate, caught up as it is in the nets of discourses that both compete and collude to define that female subject. Among other things, "Nausicaa" seems intent on attacking any presumption of innocence, as if endowing his characters with an awareness of corruption, or even a certain willingness to take advantage of it, were the only way for Joyce to give them a measure of autonomous consciousness.

\section{A preliminary reading: the moral ground as discomfort zone}

In the thirteenth episode of Ulysses, the narration focuses on Gerty McDowell, who first comes off as the stereotypical young female person of popular novels written for purposes of moral edification. As she watches after the children on the beach, Gerty muses upon uncertain prospects of love, romance and marriage, placing particular emphasis on the dignity of her humble condition and the refinement of her feelings. Accordingly, she indulges in very decent thoughts about a young and chaste suitor, wondering whether he will propose her.

Although she occasionally succumbs to passing fits of dissatisfaction with her two female acolytes, she strives to keep her temper in check, maintaining a decorum that is consistent with her self-projection as a forbearing young woman. Yet as the narrative unfolds, she gradually drops these subjects, and wishes suitor, friends and children to hell.

She was glad that something told her to put on the transparent stockings thinking Reggy Wylie might be out but that was far away. Here was that of which she had so often dreamed. It was he who mattered and there was joy on her face because she wanted him because she felt instinctively that he was like no-one else. (Ulysses 293)

This discontinuity forces the readers to realize that, contrary to their expectations, this sentimental evocation of her suitors is not part of a pseudo-realistic narrative but that the narrative follows the inconsistent, quickly changing flow of Gerty's thoughts: she has presumably been daydreaming in the style of certain melodramatic novels such as The Lamplighter by Mary Cumming, ${ }^{2}$ and fictionalizing herself, using the topoi and clichés borrowed from it as well as from girls' magazines (Richards 4, 6-7) and at this point readers understand that the flow of Gertie's thoughts is ready to take another direction.

At this point, noticing the presence of a mature man sat on a bench-for to all appearances she is the center of perception in this narrative-, she starts weaving quite another tale, casting herself in the role of the forgiving young woman who will redeem the shady past of the aforementioned gentleman. ${ }^{3}$ Most notably, in an allegorical élan 
which infuriated censors, Gerty draws an explicit parallel between the compassionate figure of the Virgin Mary and herself just before revealing her underwear to the onlooker in a passionate effusion of love (Ulysses 290, 294):

[...] and her face was suffused with a divine, an entrancing blush from straining back and he could see her other things too, nainsook knickers, the fabric that caresses the skin, better than those other pettiwidth, the green, four and eleven, on account of being white and she let him and she saw that he saw [...] (300)

What added insult to injury was that Gerty's risqué number should have been represented as a blessing. One would be well-advised to pursue the implications of that paradox beyond the merely bawdy because it is around this unorthodox appropriation that the religious and pornographic scripts become entwined in such a way that their interdependence is made palpable: confession, as I will argue in the third part of this article, relies entirely upon a supply of sins whose exposure is mandatory, which makes it intrinsically similar to pornography in this respect. ${ }^{4}$

Meanwhile, the female protagonist has become aware that the gentleman is masturbating and has decided to put on a show for his benefit. This growing awareness and the gradual indulgence in the obscene ${ }^{5}$ that accompanies it constitute the dramatic movement of the text. Its inflation of bawdy connotations climaxes in sync with what we suppose to be the voyeur's orgasm, after which the text lapses into self-justificatory reflections on his personal responsibilities in this sexual encounter.

Indeed, once the readers have reached the acme of this scene, they are likely to get a sense that the focus of the narrative has shifted back to this voyeur who is no other than Leopold Bloom, the protagonist of the novel, so that retrospectively it becomes difficult to decide whether Gerty has really collaborated in this fantasy-if not authored it-or whether it is Bloom, himself a reader of cheap sentimental fiction and erotic literature, who has made up the whole tale (Ulysses 766-776).

She walked with a certain quiet dignity characteristic of her but with care and very

slowly because-because Gerty MacDowell was...

Tight boots? No. She's lame! O!

Mr Bloom watched her as she limped away. Poor girl! (301)

This problem has been an apple of discord among the text's commentators as well as a source of fruitful critical reflections, because according to the first reading Gerty is an unwilling victim who is objectified by a man's glance while according to the second, she is an accomplice, perhaps even the instigator of the erotic game, which means that she possesses experience and agency such as the typical heroine of sentimental fiction doesn't. And, to crown it all, she has a sex life of her own. ${ }^{6}$

On that account, it seems that criticism is doomed to falter and come to a stall because it is blocked by some practical conclusion concerning the implication and significance of the chapter. Either one will reason out "Nausicaa" as a case of imaginary manipulation which projects male prejudices and fantasies upon a representative of the other sex who symbolically embodies the whole gender. Or alternately Gerty is granted -once for all-an agentivity that enables her to construct herself from the commonplaces she has gleaned from the printed press (Richards 205-248).

Yet, for all that, the question of whether one should treat the first part of the narrative as if it were the production of a character, Gerty McDowell, rather than the invention of another character, Leopold Bloom (who somehow would have a narrative prerogative since he might be the one imagining what Gerty is imagining), remains unsettled. I will have to come back subsequently to the implications of this 
undecidability. There is an evident danger in dismissing structural distinctions (notably those couched in terms of enunciative and narrative hierarchies) so as to rationalize the moral, social, or political import of Bloom or Gerty's characterization. For one may well easily end up ventriloquizing these protagonists.?

Above all, it might be argued that such evaluations, which involve a psychological assessment, are problematic, for how would one decide if a character in a fiction is another character's invention or not? What would be the alternative, then? Shall one posit that Gerty is a real person? The hypothesis may appear particularly precarious in a text which dramatizes the constitution of the self in language and insistently suggests that the social subject is summoned to appear at certain discursive places. The language of the chapter, as Morrisson has noted, is that of commercialized youth culture (5) so that the narrative persona comes off as a composite text, constituted by a patchwork of phrases compiled from magazines and serialized novels, in the same way that Bloom's fantasies are the product of his sundry readings.

Kate Mullin follows this line of reasoning, hinting that through Gerty, Joyce attacked the Social Purity Movement imposing a drastic cultural censorship at the time, in Ireland as well as in America, and that he attacked it through the medium of its own discourse, forcing the defenders of that moral stance ${ }^{8}$ to admit that the young person of their moralistic imagination was a projection that hardly concealed their own fixation on obscenity9. In other words, what "Nausicaa" revealed, lurking behind the hysterical urge to expose guilt and fault and lascivious morality in others, was just the inquiring glance of the voyeur at work. ${ }^{10}$

As for the implication of the sexual "freedom" attributed to Gerty, it may readily be interpreted as misogynistic. In a sense, it only seems to justify men's encroachment upon her privacy: ${ }^{11}$

Thankful for small mercies. Cheap too. Yours for the asking. Because they want it themselves. Their natural craving. Shoals of them every evening poured out of offices. Reserve better. Don't want it they throw it at you. Catch em alive, O. Pity they can't see themselves. (301)

"Because they want it themselves": the revulsion caused by such a pronouncement resulted in "Nausicaa"'s being caught between the conjugated hostilities of two sections of the public sphere that had quite differing worldviews, resulting in what looked like an unholy alliance between purity movement feminists and upholders of a moral order that prescribed conventional gender roles. Although conservatives and social purity feminists shared the same rhetoric, the latter was thoroughly hostile to female suffrage. Nineteenth century feminists had endorsed the Comstock act under which The Little Review was prosecuted. (Garton, 102-3). I insist on the term "revulsion," for this is a reaction caused by the text, and the way the latter engages in the register of sensationalism will be of capital importance for my examination of its operations.

Joyce has pitched the text of "Nausicaa" stylistically between two interpretative options where it sits uncomfortably so that, even today, it can be interpreted either as a gross denial of the existence of the "double standard" that consolidated its operations or as a critical exposure of it, depending on whether we understand the young woman's duplicity as an "expression of Joyce's conviction" and Bloom's fantasies as a frank honest revelation of what's on everyman's mind or consider that Bloom's behaviour is not meant to be condoned but is crudely presented in order to inspire disapproval. For instance, here is Bloom's expression of his fears after the act: ${ }^{12}$ 
But there was an infinite store of mercy in those eyes, for him too a word of pardon even though he had erred and sinned and wandered. Should a girl tell? No, a thousand times no. That was their secret, only theirs, alone in the hiding twilight and there was none to know or tell save the little bat that flew so softly through the evening to and fro and little bats don't tell. (300)

It has been argued that Joyce's attack against the social purity ideal won him his reputation. As the issue of the Little Review containing one of the installments of the text was seized by the U. S. Post Office and the magazine prosecuted for obscenity, the whole affair went public and allegedly contributed to the author's notoriety. Although Joyce might be suspected, according to Mullin, of having engineered the whole scandal, the profitability of such complications remains a debated issue (Parke 4).

At any rate, the incident refers us to the hypothetical dialogue established with the Society for the Prevention of Vice through the medium of the Little Review. In this case, it appears that the dialogue would have consisted in a literal repeat of the opponent's language, reproduced in a context where it appeared to have been compromised so that it exhibited contradictory intents. Thus Ulysses recuperates the arguments of the censors, unpacking the scabrous implications that lie dormant in them, as we shall see in the examples taken from "Circe" in the last part of this paper.

\section{Interfaces and permutations: the reversibility of discourses and critical reception}

The various critical stances elicited by the text tend to unfold in a series of polemical and contradictory arguments that feed into one another. Assessing their relative value seems to impel us to move endlessly from one position to the next. It is obviously on the nature of such turnarounds and transitions that one should focus one's attention. In order to clarify the debate, lest it should result in a series of antitheses without resolution, I propose two typologies.

To begin with, there are obviously various strands or generic discourses in the chapter which coexist problematically, neutralizing or invalidating one another. ${ }^{13}$

On the one hand, there is the narrative which constrains itself to fit the conventional idiom of young girls' magazines and the commercial adds that are inseparable from it. That conundrum is not Joyce's creative addition, it was already part and parcel of the discourse of girls' magazines..$^{14}$ (Morrisson 133-65) Joyce merely pushes it to the point where its inner disquiet is reactivated and its ideology speaks itself out. Indeed, the pastiche of nineteenth century literature of edification is so literal in the first pages of "Nausicaa" that it seems to pre-empt any possibility of technical experimentation with the language, and we may wonder why Joyce imposed upon his own art such a restriction, unless his purpose was to make the reader feel, through the literality of the prose, all the obscenity that social purity and organized prudery repressed. (This is the negativity which is everywhere at work in Joyce's fictions).

From everything in the least indelicate her finebred nature instinctively recoiled. She loathed that sort of person, the fallen women off the accommodation walk beside the Dodder that went with the soldiers and coarse men with no respect for a girl's honour, degrading the sex and being taken up to the police station. No, no: not that. (299)

The chapter also accommodates the language of religion. The latter is already replicated: not only is it to be found in the liturgy of the Catholic Mass, but it is also 
assimilated, in a moralized version, within the publications for the young person that inspire Gerty. Here again, it is difficult to neatly take the threads of that weave apart, since "Nausicaa" conflates and sets against each other two ideological constructions: that of Marian compassion and that of divine superiority and aesthetic autonomy. ${ }^{15}$

The first consists in a liberal and right-minded celebration of otherness, of an alter ego to which one might open up, which one could reach out for, through the species of love, devotion or care-a counterproductive scenario for girls aiming to achieve a sense of autonomy since it sets the problem of the maternal function and the restriction it imposes upon the female subject, all men being children, as Molly repeatedly professes.

Even if he was a protestant or methodist she could convert him easily if he truly loved her. There were wounds that wanted healing with heart balm... Then mayhap he would embrace her gently, like a real man, crushing her soft body to him, and love her, his ownest girlie, for herself alone. (293)

As for second ideological fiction, it projects an image of blessed and beatific selfsufficiency (such as only the possession of the phallus supposedly provides, hence potentially a masculine position of strength) on which the dignity of Gerty's position depends, and which allows her to remain unsullied by her own sympathetic yearnings towards a fallen man. But the demands which make themselves felt and are articulated through these role models must be understood in context. What is fictionalized is the very pressing contemporary urgency of independence that modernity required yet withheld from women.

She was a womanly woman not like other flighty girls unfeminine he had known, those cyclists showing off what they hadn't got and she just yearned to know all, to forgive all if she could make him fall in love with her, make him forget the memory of the past. (293)

Thirdly, the discourse of pornography is evidently woven into "Nausicaa". ${ }^{16}$ For our purpose, we will address it as a dual formation again, relying as it does on the possibility of corruption, hence of a putative purity that can be assaulted and defiled.

One should probably add to these the discourse of the little magazines with which "Nausicaa" is supposedly in dialogue. The reception of the episodes of Ulysses published in The Little Review is a case in point because it blurred the lines between vulgarity and distinction, eliciting two contradictory reactions. ${ }^{17}$ So that Joyce's prose was perceived by its opponents as lurid and sensationalist while its advocates chose to see it as boldly innovative, radical and demanding. In the eye of its defenders, it stood in opposition to the facile, pedestrian prose it imitated, and was meant for a discriminating and openminded reader.

This is by no means an exhaustive list of the discourses cannibalized by Joyce, and exhaustiveness is not the aim of my recapitulation. Rather, what I would like to point out at this stage is that each discourse mentioned above is already internally torn and dislocated by a constitutive problematic. The effect is that on the surface, Joyce seems content to play with the material at hand, or rather, to let it play itself out according to its own rules so that it exposes its flaws and irregularities. The inflational momentum of Joyce's writing maximizes the reach and deepens the implication of the discourses it seizes upon, throwing into relief the dramatic tensions that disturb them-the stylistic technique applied in the chapter being according to the Gilbert schemata "tumescence/ detumescence" (Joyce drafted this list of colors, body parts, symbols and art forms 
associated to each chapter in order to help Stuart Gilbert understand the general organization of the book).

The modalities of these discourses' combinations vary incessantly. Either they add up on a paradigmatic axis, thanks to the play of polysemy which allows for allusive and metaphoric double entendre; or they are arranged sequentially on the syntagmatic axis, which allows for different rhythms and alternations that alter the nuances of their proximity, whether one register passes imperceptibly into another, clashes with it or gets interlaced with other incompatible discourses in rapid succession. ${ }^{18}$

Lingerie does it. Felt for the curves inside her déshabille. Excites them also when they're. I'm all clean come and dirty me. And they like dressing one another for the sacrifice. Milly delighted with Molly's new blouse. At first. Put them all on to take them all off. Molly. Why I bought her the violet garters. Us too: the tie he wore, his lovely socks and turned-up trousers. He wore a pair of gaiters the night that first we met. His lovely shirt was shining beneath his what? of jet. Say a woman loses a charm with every pin she takes out. Pinned together. $\mathrm{O}$, Mairy lost the pin of her. Dressed up to the nines for somebody. Fashion part of their charm. (301-302)

The effects of these overlapping and conflicting discourses have elicited a number of critical opinions that sought to inquire into the accusation of obscenity and scandal generated by "Nausicaa". It seems to me that these roughly define five understandings of the situation conjured up by Joyce in the chapter, all of them casting a different light on the implications of the text.

The first one, defended by Thomas Richards (The Commodity Culture of Victorian England) suggests that "Nausicaa" consists in a crude and uncompromising presentation of the regimen of the commodity at the turn of the century which provided the rationale of relationships between the sexes. Under this perspective, the feminine press is apprehended as an ideological extension of commercial mores which encouraged female readers to construct their identity and self-consciousness along its lines, using the methods of advertisement.

On the other hand, there is a critical view which aligns with the conception of the young person championed by Margaret Anderson. Morrisson, for instance, invites us to read the chapter as a situation of empowerment predicated on the representation of youth as idealized romantic aspiration conflated with the libidinal economy of the commodity (Morrisson 133-66). Referring "Nausicaa"'s text to the circumstances of its publication in the Little Review, Morrisson insists on the emancipatory force of sexual assertiveness in the young female person which enabled her to challenge the conventional moral order of late nineteenth century.

These two options are difficult to hold together in a single assessment of "Nausicaa" since the first insists on the strategies of containment of the female subject and the determinations that bear upon her, whereas the second attaches more importance to the inventiveness and spirit of imaginative enterprise of the free woman. Yet both suggest corruption, whether in the form of fraudulent manipulation or uninhibited behaviour.

Two other positions try to negotiate between the terms of this discrepancy. One of them, that I would call anthropological, endeavors to bypass that dichotomy by positing some foundational interdependence between the well policed, regulated and monitored conception of the ideal and the disturbed and mismanaged enterprise that endangers it, between irreproachable behaviour and abjection. ${ }^{19}$ Its exponents, such as Potter (Obscene Modernism Literary Censorship and Experiment), rest their analyses against 
Nietzsche's twin concepts of Dionysian and Apollonian, Freud's notion of idealization, and more generally on the discourse of psychoanalysis which contends that repressed contents are bound to reassert themselves with fierceness proportional to the zeal that had presided over their suppression. Such accounts bind us to as set of anthropological presuppositions that may be contested..$^{20}$ Yet, at least, if one does not wish to go with their theoretical implications, they still keep their relevance as plausible sources of influence in "Nausicaa," since turn-of-the-century artists and intellectuals were conversant with such ideas that belonged with the intellectual climate of the period.

The other line of argument, notably as exposed by Allison Pease, suggests that modernism was a strategy of accommodation that attempted to bypass the prohibition placed on pornographic material meant for sexual arousal, so that it "made obscenity safe for literature" (Vanderham 57-86). In this scheme the representation of promiscuous subjects ceases to be a matter of morality altogether, staving off both censorious accounts of the visual exploitation of women's bodies and the social and ethical import of female ascendency. Aesthetics, according to Pease's view, is a form of literary appreciation which, through an effort at distanciation and contemplative detachment, seeks to wrench itself from the more common relationship to both visual and textual material where the representation is instrumental and put in the service of sensual gratification, a mode of operation whose paradigm is pornography. As I will contend, it could well be that distanciation is precisely the condition of pornography (i.e. the presentation of an image of concupiscence and carnality that relies for its effect on an assumed purity it would have the capacity to corrupt). The message of pornography is "hands off". But this prohibition is meant to generate the desire to contravene its arrangements, to infringe and encroach upon the privacy of what is ostensibly put forward as an image of desire, so that pornography and modernist scripts seem to share a fundamentally ambivalent relation to the distance existing between the consumer of indecent images and these indecent images. It can be observed that, somehow, Pease's line of argument, which relates modernism to pornography as to its antithetical opposite, can be related to the anthropological line of argument which binds idealization to abjection as to its antithetical twin, too. Indeed, Pease's argument deconstructs the distinction that brackets off the modernist enterprise from more trivial pursuits, presupposing a substratum of sensual experience always bordering on abjection behind the creative formal endeavor of the modernist writers.

I believe that all such formulations of the antithetic duality of modernism express not only its forceful uprooting from an ignominious background in the interest of artistic innovation but also the active production of such a background (just as the suspicion of abysses of vice and unfathomable depths of lewdness are capital to the pornographic effect).

Finally, there is the case made by Rabaté for a perception of Ulysses that excludes any relationship with any "other" (be they female or male or "womenly men") for the simple fact that Joyce's language abolishes any privileged relation to the name of the father. Hence the textual proliferation and a form of jubilation or jouissance in the wielding of language which is untied to any concern with another subject or subject position. Thus it remains unconcerned with romantic attachment, marriage, the constraints of a politics of the sexes or the assertiveness of any character that may stand for another subject. Joyce's purpose is, in Rabaté's view, purely egoistic. 
Those are roughly the main positions that have dominated the critical reception of "Nausicaa" and the commentators of the chapter navigate the interstices between them to achieve readings that account for the text's ambivalences and duplicity, negotiating the relative weight to be given to the terms of the dialectics they articulate (euphoria and dysphoria, passivity and activity, constraint and freedom...) and assessing the measure of their overlapping, whether they ultimately pronounce their equivalence, subversion, inversion, or transformation one into the other. ${ }^{21}$

Perhaps even more important than the exact typology of relationships between these terms is the notion of interface, either as protective border that preserves the integrity of each critical construct or allows the passing of one into the other. For this reason, I shall now turn to the (apparently) structural problem of the connection between those critical positions logically bound together thanks to various proceeds of transition, hybridation and reversal-this in order to build upon them rather than critique their theoretical foundation.

\section{The operations of ambivalence}

The gesture of empowerment that can be read in Gerty's performance is profoundly ambivalent. It is accompanied by a great discursive flow geared towards self-assertion. As Mullin demonstrates, it is consonant with a form of nineteenth century feminism which aligned itself with the recriminations and exigencies of temperance leagues (as is clear from Gerty's emphatic reference to the drinking habits of her father). The refusal to submit entirely to a patriarchal order is discernible in Gerty's attempt to carve out a space of privacy, and in the avoidance of crude contact with the other sex. But she is also working toward this aim under prodigious constrains. She endeavours to stand on her own and her imaginary construct is certainly an index of her resilience, yet she remains pinned to her seat by her infirmity, at a disadvantage, while the rest of her party move freely about her, with great velocity, a fact upon which she dwells at length and deeply resents (Ulysses 294). A leftover on the marriage market, she is left behind in more than one way, forced to contemplate the festive celebrations at a distance, and she sublimates her condition in the self-portrait she draws. These unfavorable circumstances require that she make a stand, at the risk of pride or vanity, a moral reading would imply, and Gerty's discourse registers this danger. ${ }^{22}$

From everything in the least indelicate her finebred nature instinctively recoiled. She loathed that sort of person, the fallen women off the accommodation walk beside the Dodder that went with the soldiers and coarse men with no respect for a girl's honour, degrading the sex and being taken up to the police station. No, no: not that. (298-299)

Hers is a fallback position that makes a virtue of paucity. She will stand out untouched, untouchable, virginal. But since privacy, in Foucaldian terms, is always mediated (and it is explicitly given out in "Nausicaa" as a construction meant to the address of a theoretical male observer), as soon as Gerty declares herself openly as a person whose integrity cannot be breached (even in her role of Marian consoler and provider of help, she remains uncorrupted by the opprobrium associated with the voyeur), she is bound to make an exhibition of herself since she has stepped into a spectacular apparatus. Prudery is the essential corollary to that coming out in the open: the claim for an 
autonomous self comes at the price of one's isolation. (As a French phrase has it, one may be preserved in one's virginity like potted meat or candied fruit.)

In Bloom's conception, such monitoring system is not strictly related to the immediate constraint exercised by his gaze, but it is objectified as a natural disposition (one that above all, in its ascendancy, excises the patriarchal). The train of his thoughts unfolds as a series of commonplaces meant to confirm a difference between the sexes that is grounded on a fundamental self-consciousness of the female. (It may be that the distinctions between sex, sexuality and genre are precisely what it seeks to dissolve, and that such confusion causes Bloom to run into contradictions, but on the level of the narrative flow, they are inscrutable.)

Did she know what I? Course. Like a cat sitting beyond a dog's jump. Women never meet one like that Wilkins in the high school drawing a picture of Venus with all his belongings on show. Call that innocence? Poor idiot! His wife has her work cut out for her. Never see them sit on a bench marked Wet Paint. Eyes all over them. Look under the bed for what's not there. Longing to get the fright of their lives. Sharp as needles they are. (304)

From that premise ("Did she know what I? Course."), Bloom articulates sequentially a host of clichés that the commentators of the text are forced, as a matter of method, to break down into their ideological components. But doing so, they inevitably neutralize the effect of rapid succession that favors their overlapping.

In this analogic succession, women are generally acclaimed as the weavers of illusions and, because of their mastery of that art, they are also perceived those who dispel others' illusions, who are expert at picking apart their fabric and canceling the effects of layering and covering up, the play of veils which gives the illusory object of desire a nebulous and ineffable density. Bloom pointedly reminisces of a man he once signaled to his wife's attention on account of his good looks. This incident is the feminine counterpart to the illusion by which Bloom feels he has been tricked on the beach. ("When I said to Molly the man at the corner of Cuffe street was good-looking, thought she might like, twigged at once he had a false arm. Had too. Where do they get that?" (Ulysses 304). Contrary to Bloom, Molly immediately detects the defect of the desirable figure she is presented with, without even having been caught a single instant in the spectacular apparatus.

In his internal monologue, Bloom collates all the commonplaces that distinguish women as self-conscious deceivers. The following chain of reflections is an example of that swift movement which leads us from the expression a state of alertness to the intimation of a special ability to thwart tricks: "Never see them sit on a bench marked Wet Paint. Eyes all over them. Look under the bed for what's not there. Longing to get the fright of their lives" (Ulysses 304). This anxious vigilance equally goes together with a paranoid disposition which perversely allows women to enjoy a sense of danger that they supposedly invent. It can also be interpreted as a desire to be deeply affected which they closely monitor, and the common phrases in Bloom's monologue suggest that this control system is inbuilt.

The character's concern with evidencing female subjects' natural disposition is, as we have noted above, constantly undercut by the examples he chooses. Just before revealing his prejudices, Bloom had inadvertently exposed the model of aestheticism's imposture ("Women never meet one like that Wilkins in the high school drawing a picture of Venus with all his belongings on show. Call that innocence? Poor idiot! His wife has her work cut out for her.") Such formulation invites confusion between 
voyeurism and exhibitionism, a slippage that plays into the hands of the feminine subject. That the idiomatic expression "to have one's work cut out" should involve work rather than play is not indifferent to Bloom's false consciousness.

Another similar slippage occurs when he gradually introduces the motif of the looking glass ("Milly for example drying her handkerchief on the mirror to save the ironing. Best place for an ad to catch a woman's eye on a mirror.") Here again, the importance accorded to women's relations to mirrors as evidence of some natural disposition towards self-conscious performance, one that is "bred in the bone," is undermined by the correction after "father" that marks the erasure of any atavistic paternal responsibility in such schemings: "Handed down from father to mother to daughter, I mean. Bred in the bone" (Ulysses 304).

As far as the moral aspect is concerned, everything revolves around the presumed innocence of the young female person, and its fictionalization in the debates concerned with the force of corruption of literature. (I use the word "fictionalization" in the sense that the judge and the lawyer had to conjure up a legal fiction-the average person, the man of the street-as the touchstone in their assessment of the chapter's effect on its readership). But the issue is passably complicated by the suggestion that literature can only corrupt those who are susceptible of being corrupted. (Mullin 2013, 15) Insofar as they are easily impressionable, they must certainly have a particular leaning towards vice: this argument has theological implications that we are not at leisure to investigate here but that Joyce would have been highly conscious of.

This debate leads us back to the contemporary critical dispute between those who read in Joyce's text a confirmation of male domination and those who see in it a crude exposure of its crushing violence. "Nausicaa" seems intent on attacking any presumption of innocence, as if endowing his characters with an awareness of corruption and even a certain willingness to take advantage of it were the only way for him to give them a measure of autonomous consciousness-as if these were prerequisites for the constitution of a plausible (fictional) subject. Joyce's text thus presents itself to the censors in such way that it explicitly reinforces the prejudices they hold against it, and insistently exposes its characters as corrupted.

\section{The dialectics of corruption and purity}

Although the difference between the sexes that Bloom believes he documents with the minutia of his past experiences and readings contradicts itself at every turn of phrase, still, that difference remains the main focus of his demonstration, the goal towards which he exerts his faculties of synthesis, however inconclusively. Sexual relationships, as depicted in Ulysses, require asymmetry. In its script, one protagonist must be in pursuit of the other while the latter indefatigably steals itself away. But this game of pursuit resists reduction to the binary politics of the sexes that practical feminism condemns on account of the entrenched privileges of the male subject. This is not to say that gender roles are not literally and perceptibly inscribed in Ulysses, indeed they proliferate. But the question of those who collaborate in these constructs remains open, and unanswerable, because any attempt at elucidation gets caught in an endless recursive cycle of reciprocations and retaliations, due to a persistent uncertainty as to the discursive positions of those who relate the experience. 
Since no roles are firmly assigned in this dis-symmetrical configuration, as I will try to exemplify below with reference to "Circe," the subjects keep changing position, perpetually losing their balance, so that the fantasy of being touched and contaminated is nowhere so close at hand than when one has the assurance that the gulf is insuperable, and this superior sense of incorruptibility only exacerbates the urge to abolish it. (Bloom muses upon his experience on the beach: "Excites them also when they're. I'm all clean come and dirty me. And they like dressing one another for the sacrifice.)

All in all, the situation involving a voyeur and an innocent creature that is being espied into a visual apparatus requires a measure of bad faith that is not clearly attributable to any party, and both symptomatically deflect the blame upon the other. The form of this paradox is most clearly exposed in "Circe," a chapter which I take to be, among other things a subtext, a recapitulation and a deepening of "Nausicaa"'s implications. ${ }^{23}$ In its opening scene, Gerty, who is ostensibly presented as a figment of Bloom's imagination, appears to bear all the duplicity: first remonstrating her putative corrupter for having taken her virginity ("You did that I hate you" Ulysses 361), her accusation is immediately superseded by her admission that "I love you for doing that to me". This is, I believe, the very matrix of the voyeuristic configuration. ${ }^{24}$ Although not guilty of that charge, Bloom lies about it: "I, when, I never saw you". His denial suggests that the verb "to see" functions as a metaphor for some illicit touch. His dodges leave all the blame entire, his lame attempt at exculpating himself from the sexual assault of innocent young women eventually resulting in unintelligible verbiage (Ulysses 376, 378). At that point, we reach the limit of the social use of language, the moment when it crumbles into meaningless and useless glossolalia). Nonetheless the fault is publicly exposed.

In the imaginary tribunal that Bloom conjures up, he stands guilty before the court of licentious thoughts, and the crimes he confesses or which are blamed upon him only exist in his mind. Bloom testifies to the fact of having had erotic thoughts about excretive organs. Or to put it slightly differently, he admits having conceived that body parts exerting an erotic fascination or attraction also had excretive functions, holding these two thoughts in his mind at the same time. ("Enemas too I have administered... I have paid homage on that living altar where the back changes name"). This admission sits in between an idealization of the female object of desire and the defacement of its purity by the vulgarity of what it celebrates. (Ulysses 449) What is of relevance in the reasoning I am trying to pursue is this simultaneity. Again, commentators of Ulysses who dwell with good reasons on the proximity between sexual attraction and abjection go back on the defense undertaken by Quinn who posited that the repulsive presentation of sex chosen by Joyce could not be attractive, hence his prose could not be defined as pornographic.

Eventually, Bloom breaks the charm: without desire and sexuality, the ethereal would not exist. ("If there were only ethereal where would you be all, postulants and novices? Shy but willing like an ass pissing." Ulysses 451) His attack on virtue is both libelous, defiling its target, and elucidatory. It aggressively flings the accusation back at the figure who issued it, in such a way that he actually breaches the integrity of the fictional persona's identity and jeopardizes her metaphysical existence. Here as well, that coincidence of cruelty and justice in the same observation has much significance for my account: 


\section{THE NYMPH}

(With a cry flees from him unveiled, the plaster cast, cracking, a cloud of stench escaping from the cracks) Poli...!

\section{BLOOM}

(calls after her) As if you didn't get it on the double yourself. No jerk and multiple mucosities all over you. Your strength our weakness. What's our studfee? What will you pay on the nail? You fee men dancers on the Riviera, I read. (451)

Whoever utters seditious and defamatory words can only be perverse. ${ }^{25}$ Any statement that hurts the feelings and upsets one's sense of self-respect has to be the language of the pervert. It has to be so, at any cost, for no other explanation will do. The blame must be deflected upon the one whose language is audibly fraught with distasteful innuendoes, otherwise it would leave one with the responsibility of confronting the disquiet occasioned by the pervert's presence as a personal matter, and recognize one's own suppressed attraction towards what one figures in it. ${ }^{26}$ This is an exorcism of sort whereby the condemnable vice is externalized and any degree of closeness between the offense and oneself is denied. One does not want to have anything to do with it, or register it as anything but an inconvenience. For any rapprochement would involve the danger of contamination. Yet the possibility of such contamination suggests a compatibility, a capacity to be affected by such noxious influence, hence the kinship that it overtly denies. For fear of infection, it must be expurgated and purified. The elaboration of purity as discourse and performance is motivated by that evasion.

Jastrebski underscores the popular, lowly extraction of the Nymph pinned on the wall of Bloom's bedroom (Jastrebski 172). This mythological figure has been cut out from the pages of a magazine where it had to suffer the infamous proximity of slimming pills, music hall celebrities and mummer shows.

Mortal! You found me in evil company, high kickers, coster picnic makers, pugilists, popular generals, immoral panto boys in fleshtights and the nifty shimmy dancers, La Aurora and Karini, musical act, the hit of the century. I was hidden in cheap pink paper that smelt of rock oil. I was surrounded by the stale smut of clubmen, stories to disturb callow youth, ads for transparencies, truedup dice and bustpads, proprietary articles and why wear a truss with testimonial from ruptured gentleman. Useful hints to the married. (444)

It is by its forcible extraction from the company of its peers that it acquires the distinctive and distinguished aura that is also the source of her humiliation. That compartmentalization, which it is difficult to tell whether it is willed, in an act of selfconsciousness, or imposed by the admiring glance that raises the Nymph to the position of icon, eventually denaturalizes her so that, taken out of her prosaic context, she suffers from being thus circumscribed. That the suffering might be the result of this enforced detachment is an aspect that commands our attention.

The cult to which the Nymph is subjected is tantamount to her subjugation and humiliation. She keenly registers the offense: her strong reaction to Bloom's verbal sally touches her to the quick. In this situation where she articulates her recriminations, she actuates all the feelings, mortified as she is by Bloom's idolatry, and her overflowing wrath instantly transforms into the abjection which sullies her reputation. Since total simultaneity is unconceivable in a narration of events, the aspects of her aporetical condition must perforce come apart in the dramatization of the episode. The latter only reproduces these states of consciousness as contradictory movements so that they appear as successive takes on her predicament, motions affecting the thymia, transformations of her mood. 
Likewise, the critical commentators who wish to describe the functioning of the text, to enumerate its proceeds and its thematics, are bound to describe them as disjointed phases, moments of glories and infamies, in an artificially frozen succession of tableaux.

The paradox on which I have concentrated so far, the one that makes and mars the reception of "Nausicaa" spells out the condition of the image of desire. Namely: that the desirable figures of the text create their ignominious condition as they detach themselves from the common ground of existence that they had to bear with. ${ }^{27}$

Just as the nymph on the picture hung up above the bed in Bloom's bedroom is perceived as a temptress eluding Bloom's grasp, whose shell peals and cracks up, oozing a viscous fluid, as she is disavowed by her admirer, so Gerty is carried away by her impersonation of the proud and authoritative "womanly woman". As I have shown, any moral implication of that statement to the effect that the female character has simply brought upon her her own shame and that she deserves such treatment would be irrelevant, owing to the impossibility of identifying oneself durably with Gerty-or with Bloom for that matter-these subject positions being illusory throughout.

Self-empowerment, standing out of the rank and raising up to a position of visibility actuates a situation of maximum exposure. It entails an extreme vulnerability and susceptibility which invite degradation. (The nature of this invitation inevitably sends us back to that difficult question of the female person's share of initiative in Joyce's design and I will not try to neutralize the moral scandal it involves for it is this explosive charge the episode is loaded with).

In Bloom's view, women signal themselves as available to the attention of their admirers-and to that attention only-but, as the Nymph insistently protests, she is not one of these women. She shrinks from any contact. Coming out in the open entails vulnerability. One must therefore put on a good face and watch one's moves. That is: carefully monitor one's appearances, an enterprise that is all too readily interpreted as one of seduction.

Whoever expresses that quandary will be charged with the full responsibility of what he exposes. (The positions of voyeur and exhibitionist are significantly interchangeable in the circular plot of humiliation and redemption of "Circe"). The sacrificial function of the figure of the sex offender is explicitly noted.

When in doubt persecute Bloom. My client, an innately bashful man, would be the last man in the world to do anything ungentlemanly which injured modesty could object to or cast a stone at a girl who took the wrong turning when some dastard, responsible for her condition, had worked his own sweet will on her.

All the blame should be laid on Bloom. So that the assurance that he would not have behaved with Mary Driscoll otherwise than he would with his own daughter becomes instantly loaded with double entendre aggravating his crime. ("The young person was treated by defendant as if she were his very own daughter.") The language of Bloom's lawyer only further compromises his client. In the scapegoating configuration, whoever undertakes the defense of unmentionable crimes is liable to lose their good name (378). 


\section{Conclusion}

In "Nausicaa," Joyce actuates and sets at work in his writing the duplicity that underlies the defense of temperance and purity, giving free play to its corrupting force. To begin with, whoever hoists the banner of purity and holds out to everyone's attention the moral exemplum of the young female person also implies and plays upon the possibility of her degradation and capitalizes, to maximize its impact, on the danger to which she is exposed and the thrill that such perspective inspires. In short, those who conjure up an angelic vision also think into existence the bestial antithesis against which it stands out.

Thus phrased, this remark does not substantially enlarge on Pascal's dictum. An addition must made to clarify its implication. The point is that, as long as criticism is intent on denunciation, whether it sides with the text or takes arms against it, uncovering some injustice or immorality, it will go round and feed the same vicious/ virtuous cycle that it purports to explore. For instance, we may legitimately aim at exposing in its scandalous nudity the lowliness that underpinned the attempts of morality leagues, arguing righteously that they evacuated their own trouble, refusing to reflect upon the nature of their own response whenever their taste was offended. But such a postulate does not rescue us from our critical predicament. The blandest version of this counter-moralizing or anticlerical argument holds that the paragons of virtue read dirty literature under the cloak, and that they secretly indulge into what they reprove in others. But that formulation merely initiates a new wave of recrimination.

As long as criticism does not desist from forcefully expelling the pervert as a matter of principle in the name of some sort of virtue, it will recreate that same figure of the pervert, the man (man and not woman) who should know better, who should be past the age of obscenities (note that Bloom's infantile regression in "Circe" is one of his means of evasion).

And as long as one will pit against this repulsive nudity another more dignified and unsoiled nakedness that would only signify innocence, then this line of criticism will reconstruct the virginal image that calls for its defilement. And those who take offense at the suggestions of perversion contained in that "call for defilement" and charge whoever mentions it with being the one that conceives such lewd thoughts refuel the same critical machinery. They will not even have begun to emerge from the contradictions of the holy/unholy alliance of chastiser and chastized, from the see-saw movement of reversals and turnarounds that Joyce dramatizes-the Apostolic Church, the British Crown, Old Ireland, the Patriots, each in turn keep castigating and heaping abuse on one another, in a great circular parade.

The description of the character of Gerty, of Gerty as Gerty envisions herself, is twofaced. The term "duplicity" itself is misleading, too easy to neutralize so as to affirm the purity of one's intent, and I hope I have managed at least to convey this idea that the existence of a purity of intent that is the immediate cause of its corruption. In the criticism of "Nausicaa", it is of crucial importance to understand that the virginal figure to which Gerty relates and on which she relies is obscenity itself, not its flipside, its double or evil twin. If the critics miss this nuance, the effect of the text upon them will be corrupting, they will have been caught by its pull, they will have themselves become the chastizers, the denunciators of the vice that lies at the bottom, under the 
pretence of the virtuous. Such is the movement that Joyce's text encourages. Perhaps its effect will always remain perversive. Its specificity is that it forces its readers to experience these disagreeable twists reluctantly, against their will, and without hope of disciplining and regulating their confusing impressions. For such reduction could only be achieved at the cost of their exclusion from the fictional pact (as should be clear, at this stage such pact cannot be equated with a writer-reader contract). And even this distanced position will not guarantee their safety, for that very reluctance to engage with the text will arouse suspicion.

\section{BIBLIOGRAPHY}

Anderson, Margaret C. My Thirty Years War: An Autobiography. 1930. New York: Horizon Press, 1969.

Austin, Linda M. “Ruskin and the Ideal Woman." South Central Review, 4, 4 (1987): 28-39.

Bachman, Erik. Literary Obscenities: U.S. Case Law and Naturalism after Modernism, Pennsylvania: Penn State University Press, 2018.

Birmingham, Kevin. The Most Dangerous Book: The Battle for James Joyce's Ulysses. New York: Penguin, 2014.

Brown, Richard. Joyce and Sexuality. Cambridge: Cambridge University Press, 1985.

Cotter, David. James Joyce and the Perverse Ideal. New York, London: Routledge, 2003.

Driscoll, Catherine. “Feminist Audiences for Joyce.” Joyce's Audiences. Ed. John Nash, European Joyce Studies 14, Amsterdam: Rodopi (2002): 179-200.

Garton, Stephen. Histories of Sexuality: Antiquity to Sexual Revolution. New York: Routledge, 2004.

Heap, Jane. “Art and the Law.” Little Review 7.3 (1920): 5-7.

Henke, Suzette and Elaine Unkeless (eds.) Women in Joyce. Urbana: University of Illinois press, 1982.

Jastrebski, Joan. “Pig Dialectics: Women's Bodies as Performed Dialectical Images in the Circe Episode of Ulysses." In Joyce and the Fabrication of Irish Identity. Ed. Michael Patrick Gillespie. Amsterdam: Rodopi, 2001, 151-175.

Joyce, James. Ulysses. Harmondsworth: Penguin, 1986.

Kupinse, William. "Household Trash: Domesticity and National Identity in The Lamplighter and the 'Nausicaa' Episode of Ulysses.” South Carolina Review 32.1 (1999): 81-87.

Marek, Jayne E. Women Editing Modernism. Lexington: University Press of Kentucky, 1995.

Morrisson, Mark. The Public Face of Modernism: Little Magazines, Audiences, and Reception, 1905-1920.

Madison: University of Wisconsin Press, 2000. 
Mullin, Katherine. James Joyce, Sexuality and Social Purity. Cambridge: Cambridge University Press, 2003.

Mullin, Katherine. "Poison More Acid than Prussic Acid: Defining Obscenity after the 1857 Publication Act." In Prudes on the Prowl. Fiction and Obscenity in England, 1850 to the Present Day. Ed. Rachel Potter \& David Bradshaw. Oxford: Oxford University Press, 2013. 11-29.

Parkes, Adam. Modernism and the Theater of Censorship. New York: Oxford UP, 1996.

Pease, Allison. Modernism, Mass Culture, and the Aesthetics of Obscenity. New York: Cambridge University Press, 2000.

Potter, Rachel. Obscene Modernism: Literary Censorship and Experiment 1900-1940. Oxford: Oxford University Press, 2013.

Potter, Rachel \& David Bradshaw (eds). Prudes on the Prowl: Fiction and Obscenity in England, 1850 to the Present Day. Oxford: Oxford University Press, 2013.

Potter, Rachel. “'Can my daughter of 18 read this book?': Ulysses and Obscenity.” Critical Quarterly 46. 4 (2004): 22-37.

Rabaté, Jean-Michel. James Joyce and the Politics of Egoism. Cambridge: CUP, 2001.

Richards, Thomas. The Commodity Culture of Victorian England. Stanford, CA: Stanford University Press, 1991.

Rice, Carla. Becoming Woman: the Embodied Self in Image Culture. Toronto: University of Toronto Press, 2004.

Russo, Mary. The Female Grotesque: Risk, Excess and Modernity. London: Routledge, 1995.

Scott, Bonnie Kime. Refiguring Modernism, vol.1, The Women of 1928. Bloomington: Indiana University Press, 1995.

Sicker, Philip. "Unveiling desire: pleasure, power and masquerade in Joyce's 'Nausicaa' episode." Joyce Studies Annual, 14 (2003): 92-131.

Stearns, Thaine. “The 'Woman of No Appearance': James Joyce, Dora Marsden, and Competitive Pilfering." Twentieth Century Literature, 48, 4 (2002): 461-486.

Vanderham, Paul. James Joyce and Censorship: the Trials of Ulysses. New York: New York University Press, 1998.

\section{NOTES}

1. Our working definition of obscenity is derived from this trial: what was at stake was the capacity of certain literary materials to corrupt the reader and encourage lewd thoughts. These terms had already been established as a standard fifty-three years before: "According to Lord Chief Justice Alexander Cockburn in Regina v. Hicklin (1868), the test for obscenity involved simply the determination of "whether the tendency of the matter charged as obscenity is to deprave and corrupt those whose minds are open to such immoral influences, and into whose hands a publication of this sort may fall." This is a pragmatic definition which characterizes obscenity by what it does, not what it is, as Bachman observes (Bachman 1).

2. The exact measure of the influence of Mary Cummings' novel is contested. Potter makes the case for a thorough rewriting of The Lamplighter (Potter 2004) and William K. Kupinse recapitulates its possible implications (Kupinse 81-87). 
3. "If he had suffered, more sinned against than sinning, or even, even, if he had been himself a sinner, a wicked man, she cared not. Even if he was a protestant or methodist she could convert him easily if he truly loved her".

4. In the fifth chapter of Ulysses, Bloom ponders on the institution of confession: "Wonderful organisation certainly, goes like clockwork. Confession. Everyone wants to. Then I will tell you all. Penance. Punish me, please. Great weapon in their hands. More than doctor or solicitor. Woman dying to. And I schschschschschsch. And did you chachachachacha? And why did you?" (28).

5. Again, the obscene spectacle is meant to stir desire and invite sexual behavior of a deviant kind.

6. This perception reflects Jane Heap's observation: "if there is anything I really fear it is the mind of the young person". (Heap 5-7). As we shall see, most of the critical positions adopted by contemporary have been anticipated by the first reactions it elicited on the occasion of its publication in serialized form.

7. Here again the reaction elicited on the occasion of the 1921 trial by the treatment of the case already set the terms of this critical response (Parkes 76).

8. One may wonder whether "Nausicaa" was in any manner destined to the attention of the Society for the Suppression of Vice. That Joyce had become entangled in a dispute with them is one thing, that his prose was addressed to them is another.

9. That is, according to our definition, on what, in the spectacle of the vulnerable virgin, elicits pleasure and causes excitement.

10. This was a frequent objection raised against the zeal of the censors, as Potter Observes, one that Windham Lewis used on the subject of Ulysses and Eliot on that of Lawrence's painting (Potter 2013, 55-58).

11. All the more so since this common insinuation is immediately contradicted by another fragment of opinion according to which it is a "Pity they cant see themselves"-the latter being at variance with the accusation of self-consciousness that Bloom documents throughout his tirade.

12. Adam Parke's reading of the passage is that Bloom's point of view is dominant in it (Parke 83.). Denis Donoghue inclines the same way in The Practice of Reading (229-231). Although this interpretation might be contested (and the text is certainly designed to be contested), one has to admit at least that Gerty's and Bloom's narratives blend in the transition from one to the other. All the examples featured below involve some inconsistency in the enunciation and thereby illustrate the uncertainties-that I have evoked in the introduction-about the position the reader should adopt. Here, the narrative blends Gerty's sentimentalism with Bloom's strategy of concealment in a way that precludes us from to locating the source of enunciation.

13. That the virginal young woman of Catholic disposition does not obsess on petticoats and knickers, does not aggrandize herself and abstains from self-serving behavior should be obvious. And least of all does she indulge in pornography.

14. All the products enhancing physical beauty that Gerty mentions aim at drawing potential husbands by making herself sexually attractive, on the model of the "lovely seaside girls" massively commodified in advertising. They invite the consumers/readers to adopt the deviant position of voyeur or exhibitionist, setting the template for the peep show situation that Bloom references: "Mutoscope pictures in Capel street: for men only. Peeping Tom. Willy's hat and what the girls did with it. Do they snapshot those girls or is it all a fake? Lingerie does it. Felt for the curves inside her déshabillé. Excites them also when they're. I'm all clean come and dirty me. And they like dressing one another for the sacrifice" (301).

15. The process of singling out, celebrating and elevating remarkable women inherited from Ruskin's ideal and more generally, from the Victorian worldview, relies heavily on sublimated images of the female body that pictorial conventions recommend. To phrase the point slightly 
differently, the bid for autonomy has to be performed visually in a social context as aesthetic integrity (Austin). As Carla Rice puts it, "[f]or girls coming of age in consumerist, individualist and media driven cultures, the body has become an important identity project" (3).

16. It rests on the methodical exploitation of obscene material for their sexually stimulating properties. As Lynn Hunt contends, the term was introduced as a regulating category to cordon off licentious cultural products from women and the lower class, for fear it would corrupt them (Hunt 19). Pornography thus became a genre or province of literature whose motifs, tropes patterns and stock situations could be parodied, and they are evidently quoted as such in "Nausicaa".

17. Sometimes in the same reader, as was the case with Pound for instance, according to Paul Vanderham (19-27).

18. For a more substantial study of these variations, see the comments on Bloom's train of thought in the third part of this study. Insofar as paradigmatic substitutions are concerned, one notes that Joyce does not rely on metaphorical language, mostly leaving it to the characters. Conversely, he exploits common phrases which he uses in an improper context conducive to bawdy insinuations.

19. Insofar as the two views presented above are concerned, its implications are straightforward: the liberatory force of the modern individualism embraced by young womenmay well stand in opposition to their despicable commercial instrumentalization, this does not entail that the first can be conceived without the second.

Likewise, one may resent being enslaved to one's passions. But refusing to be subjected to them would fail to procure a higher ground for life since it would suppress the vital energies on which that life depends.

20. Freud's insufficient theorization of the female psyche as distinct from the male libido has been deplored by feminists and made him a disputable reference. Still, his insights have been significantly prolonged by Kristeva's notion of abjection, which undoubtedly casts a light on the episode under study. As for Nietzsche, like Freud, his dependence on $19^{\text {th }}$ century science as well as on the cultural prejudices of his time is sometimes invoked as a hindrance to his use in the humanities.

21. On the model of Bloom's protestation that he would not do to Mary Driscoll (whom he is accused of having assaulted) any more than he would to his own daughter, a statement undermined by the fact that he has brought together Milly and Gerty in the course of his associative thinking.

22. This also seems to be Mary Driscoll's position when summoned to appear before the court to give evidence against Bloom. There she explains her refusal to yield to his solicitations by stating "I thought better of myself poor as I am," thus combining the discourse of self-empowerment and the discipline of humility.

23. Ulysses, in its serialized form, as has been amply documented, keeps track of the debate on obscenity in the press. Its subject matter and allusions respond to the episodes of its own censure and publication. Its pastiches of self righteous discourse and moral prescriptions are done in imitation of journalistic prose. In short, it responds to the constraints imposed by the censors.

24. It has been objected to me while presenting this paper in a conference that in a post \#metoo world, one would be expected to name the perpetrator of abuse: is the duplicity of the feminine object a fantasy production of the voyeur (Bloom), or a characterial trait ascribed to Gerty by the author? At the end of the first section of this essay, I made the case for a textual construct that systematically lent itself to contrary judgments. The most outstanding case is the dream scene in "Circe" where Bloom is first celebrated for his humane behavior before being tried for sexual misconduct. On this occasion, many women reveal that they have been victims of sexual harassment at his hands, two of them declaring:

MRS BELLINGHAM: Me too. 
MRS YELVERTON BARRY: Me too.

Yet considering that Bloom displays masochistic tendencies and welcomes the ladies' threats of corporeal punishment with thrilled abandon, one may wonder if he has not conjured up this scene, offenses included, for the sole purpose to tease himself. In this context, defining Bloom's actual crime is as scattershot and risky as estimating Joyce's complicity with his character.

25. This, again, is a pragmatic definition of perversion, understood in terms of the effect it has on other subjects. It is the flipside of the more obvious description according to which the pervert is the one whose behaviour deviates from normalcy, and who is not content with yielding to depravity but assiduously desires this degradation. But in both definitions, the meaning is relative to specific periods and mores. In Joyce's text, it is related to the Catholic notions of sin and vice.

26. As Rabaté notes, Joyce "quotes the famous statement Wilde gave as a defense of his only novel to the Scots Observer and then generalizes boldly: Everyone, he wrote, sees his own sin in Dorian Gray (Wilde's best known novel). What Dorian Gray's sin was no one says and no one knows. Anyone who recognizes it has committed it.' (Rabaté 170).

27. In this, it resembles the condition of meaning as Derrida envisages it: positing a stable concept requires to set against adverse notions, so that the concept may present distinct outlines. Yet this operation necessarily excludes something that is part of its constitution, Derrida argues. For this reason it has to be distinguished from a dialectic turn, for it does not involve the overcoming of a contradiction between antithetical terms, nor the disclosure of some imposture which would cover up a concealed intention.

\section{ABSTRACTS}

This article concerns the presence of obscene contents in Ulysses and the embarrassment that such material has caused among its readers. It dwells more specifically on the thirteenth episode of the novel, "Nausicaa". After recapitulating the main arguments put forward by scholars in response to the most unpalatable and morally touchy aspects of the episode, I propose to concentrate on the internal contradictions elicited by the various discourses woven together in it. I argue that the narrative apparatus set up by the author forces one to occupy unstable positions and that this instability is what has led to the different critical receptions of Joyce's text. By exposing the reader to contradictory imperatives, this narrative apparatus aims at conflating virtue and vice into a single entity.

Cet article concerne la présence de contenus obscènes dans Ulysses et l'embarras que ce matériau littéraire a causé et cause encore chez ses lecteurs. Il se concentre plus particulièrement sur le treizième épisode du roman, "Nausicaa". Après avoir récapitulé les arguments principaux exposés par les universitaires en réponse aux aspects les plus dérangeants et moralement suspects de l'épisode, je me propose de me concentrer sur les contradictions internes des divers discours qui s'entrelacent dans le texte de Joyce. Mon argument est que le dispositif narratif mis en place par l'auteur nous force à occuper des positions instables et que ces instabilités déterminent les différentes réceptions critiques du texte de Joyce. En exposant son lecteur à des impératifs contradictoires, il vise à confondre la vertu et le vice en une seule entité. 
INDEX

Keywords: interface, James Joyce, narrative apparatus, "Nausicaa, " moral scandal, obscenity, public exposure, Ulysses, visibility, voyeurism

Mots-clés: dispositif narratif, exhibition, interface, James Joyce, "Nausicaa”, obscénité, Ulysse, scandale moral, visibilité, voyeurisme

\section{AUTHOR}

\section{PHILIPPE BIRGY}

Professor

Université Toulouse-Jean Jaurès

birgy@univ-tlse2.fr 